\author{
Sebastian Kokot* \\ Uniwersytet Szczeciński
}

\title{
UWAGI O METODACH WYZNACZANIA INDEKSÓW CEN NIERUCHOMOŚCI
}

\begin{abstract}
Streszczenie
Indeksy cen nieruchomości są cenną informacją dla analityków rynku, inwestorów i reprezentantów innych profesji związanych z rynkiem nieruchomości. Ponadto zgodnie z obowiązującymi przepisami indeksy winny być stosowane w określonych celach prawnych. W praktyce funkcjonuje kilka metod wyznaczania indeksów cen nieruchomości. Wszystkie mają swoje wady i zalety i odzwierciedlają rzeczywiste ruchy cen na rynku z różną dokładnością. W artykule podjęto próbę charakterystyki poszczególnych grup metod, w szczególności z punktu widzenia potencjalnego ryzyka wiarygodności uzyskiwanych wyników.
\end{abstract}

Słowa kluczowe: rynek nieruchomości, indeksy cen nieruchomości

\section{Wprowadzenie}

Obserwacja ruchów cen na rynku nieruchomości jest trudna. Trudność ta wynika przede wszystkim ze specyfiki rynku nieruchomości powodującej, że konstruowanie indeksów cen nieruchomości metodami tradycyjnymi jest niemożliwe (Wood 2005). Na rynku nieruchomości obserwacja cen jest niestandardowa (Kokot 2015a), gdyż poszczególne transakcje dotyczą zróżnicowanych przedmiotów i zachodzą

* Adres e-mail: sebastian.kokot@wneiz.pl. 
w nieregularnych (poniekąd przypadkowych) okresach. Poszczególne nieruchomości charakteryzują się innymi cechami rynkowymi oraz cechami specyficznymi. Cechy rynkowe to takie, co do których można chociaż w przybliżeniu określić ich wpływ na wartość nieruchomości, a przez to na przewidywany poziom możliwej do uzyskania na rynku ceny. W segmencie mieszkań mogą to być: lokalizacja, otoczenie (najbliższe sąsiedztwo), stan techniczny i rodzaj budynku, powierzchnia mieszkania, układ funkcjonalny mieszkania, położenie mieszkania w budynku (które piętro, ekspozycja południowa czy północna), standard wykończenia itp. Cechy specyficzne to cechy nieruchomości, których wpływ na wartość nieruchomości bardzo trudno określić, lecz w konkretnych przypadkach mogą mieć wpływ na cenę, gdyż mogą być odmiennie postrzegane przez różnych potencjalnych nabywców. W przypadku lokalu mieszkalnego mogą to być: wyposażenie w kabinę prysznicową lub wannę, kolor kafelków, styl urządzenia wnętrza, wyposażenie lokalu lub budynku w urządzenia istotne dla konkretnego nabywcy (zsyp na śmieci, winda), położenie w miejscu atrakcyjnym dla konkretnego nabywcy (np. blisko miejsca pracy, blisko rodziców lub blisko przystanku konkretnej linii tramwajowej) (Kokot, Bas 2015). Wskutek splotu tych wszystkich cech nieruchomości oraz innych, niezidentyfikowanych pobudek poszczególnych nabywców mamy do czynienia z występującymi na rynku relatywnie mocno zróżnicowanymi przedmiotami obrotu i odnoszącymi się do nich też zróżnicowanymi cenami transakcyjnymi. $Z$ tego powodu przy konstruowaniu indeksów cen nieruchomości problem niejednorodności przedmiotów obrotu w różnych okresach ma charakter kluczowy (Guo, Zheng, Geltner, Liu 2014). Tymczasem zainteresowanie możliwością dostępu do informacji o tym, czy nieruchomości drożeją, czy tanieją, i w jakim tempie, zgłasza wiele instytucji finansowych, a nawet osób prywatnych (Francke 2010). Ponadto w Polsce konieczność posługiwania się wskaźnikami cen nieruchomości w pewnych celach prawnych wynika wprost z określonych przepisów. Zgodnie z ustawą o gospodarce nieruchomościami wskaźniki takie mają być stosowane m.in. przy obliczaniu: zwrotu bonifikaty udzielonej w cenie nieruchomości, jeżeli nabywca sprzedał nieruchomość przed upływem czasu ustalonego w ustawie, wypłaty odszkodowań za wywłaszczone nieruchomości, zwrotu odszkodowania za wywłaszczone nieruchomości, jeżeli następuje zwrot tej nieruchomości, opłaty adiacenckiej z tytułu wzrostu wartości spowodowanego pojedynczym podziałem i budową urządzeń infrastruktury technicznej, a także przy przeszacowywaniu wartości katastralnej oraz przy obliczaniu zwrotu sumy opłat 
rocznych pobranych od użytkownika wieczystego w razie rozwiązania umowy użytkowania wieczystego przed terminem (Kokot 2014). Naturalnie powstaje więc problem, jak wyznaczyć wskaźniki cen nieruchomości, które by w miarę dobrze odzwierciadlały ruchy cenowe na rynku nieruchomości. Problematyka metod badania dynamiki cen na rynku nieruchomości wciąż jest przedmiotem zainteresowania naukowców, a dokładne oszacowanie wskaźników cen dla nieruchomości stanowi zasadniczy problem badań rynku nieruchomości (Clapp, Giacotto 1992).

Podstawowym źródłem danych do obliczania wskaźników cen nieruchomości są ceny transakcyjne. Operowanie cenami transakcyjnymi na potrzeby wyznaczania indeksów cen nieruchomości jest problematyczne również z następujących powodów (Kokot 2015b):

a) mała liczba danych o transakcjach (mało transakcji na rynku);

b) zbyt ubogie informacje o nieruchomościach zawarte w aktach notarialnych, niekiedy uniemożliwiające identyfikację podstawowych cech nieruchomości, a przez to trudność stwierdzenia adekwatności ceny jednostkowej do przedmiotu obrotu (np. posługiwanie się różnymi jednostkami określającymi wielkość nieruchomości, jak: kubatura, powierzchnia zabudowy, powierzchnia ogólna, powierzchnia użytkowa);

c) nieprawdziwe informacje o cenach transakcyjnych w aktach notarialnych - $\mathrm{z}$ różnych powodów ceny bywają zaniżane lub zawyżane;

d) błędy powstające przy wprowadzaniu danych z aktów notarialnych do rejestrów cen i wartości;

e) duże opóźnienia we wprowadzaniu danych z aktów notarialnych do rejestrów cen i wartości.

O ile problemy wymienione w punktach b-e można uznać za techniczno-organizacyjne, o tyle problem wymieniony jako pierwszy wynika z charakterystycznych cech rynku nieruchomości i może stanowić podstawową barierę przy konstruowaniu indeksów cen nieruchomości (Bokhari, Geltner 2010).

W tym kontekście celem artykułu jest wskazanie wad i zalet stosowanych metod wyznaczania indeksów cen nieruchomości oraz ich dyskusja. 


\section{Metody wyznaczania indeksów cen nieruchomości}

Mimo wymienionych problemów naukowcy nie ustają w wysiłkach nad opracowywaniem nowych i doskonaleniem tradycyjnych metod wyznaczania indeksów cen dla rynków nieruchomości. Opracowane dotychczas metody można najogólniej podzielić na trzy grupy:

1. Metody polegające na obserwacji zmian średnich cen obliczanych z transakcyjnych cen jednostkowych odnotowanych na danym rynku w danym okresie.

2. Metody oparte na analizie powtórnych sprzedaży.

3. Metody wykorzystujące modele hedoniczne.

Wszystkie metody mają tak swoje zalety, jak i wady, co przekłada się na różnąjakość uzyskiwanych przy ich zastosowaniu wyników i różną ich aplikacyjność w praktyce.

\section{Dyskusja}

Poniżej dokonano próby zwięzłego wyspecyfikowania podstawowych zalet i wad poszczególnych metod wyznaczania indeksów cen nieruchomości.

Ad 1. Istotą pierwszej grupy metod jest obliczenie średniej (zwykle średniej arytmetycznej, mediany lub dominanty) $\mathrm{z}$ cen zaistniałych $\mathrm{w}$ danym okresie na rynku i odniesienie jej do analogicznej średniej z okresu poprzedniego, bez zwracania uwagi na aspekty związane $\mathrm{z}$ jednorodnością próby. W nieco zaawansowanej odmianie tej metody można wyznaczać wskaźniki dla bardziej jednorodnych grup nieruchomości - np. wyodrębnionych ze względu na położenie nieruchomości, grupy powierzchniowe czy rodzaj prawa do nieruchomości. Do podstawowych zalet takich metod należy zaliczyć prostotę obliczeń, brak wymogu dysponowania szczegółowymi informacjami o cechach nieruchomości, a także łatwość interpretacji wynikającą $\mathrm{z}$ bezpośredniego odniesienia wyników do meritum badanego zjawiska - uzyskane wartości indeksów wprost mówią o zmianach średnich cen. Metody takie mają jednak wady na tyle poważne, że w praktyce dyskwalifikują je w czystej postaci jako narzędzie analityczne. Główną wadą metod opartych na średnich cenach transakcyjnych jest to, że w różnych okresach średnie są obliczane w próbach zróżnicowanych pod względem struktury jakościowej, co jest pochodną specyfiki rynku nieruchomości (o czym była mowa we wprowadzeniu). Ponadto należy się liczyć z tym, że część odnotowanych cen może być przekłamana lub błędna oraz że dostęp do kompletnych danych zwykle następuje z wielomiesięcznym opóźnieniem. Jako badacze nie mamy wpływu na to, co na rynku się dzieje, lecz musimy ,z pokorą” zjawiska 
na nim zachodzące odnotowywać. W konsekwencji uzyskujemy, nawet na rozwiniętych rynkach nieruchomości, w poszczególnych okresach średnie ceny na tyle zróżnicowane, że obliczone na ich podstawie indeksy wskazują na tak duże zmiany cen z okresu na okres, iż obiektywnie, a nawet intuicyjnie zmiany te postrzegane są jako niewiarygodne. Zobrazowano to na rysunkach 1-2. Na rysunku 1 przedstawiono miesięczne mediany cen jednostkowych mieszkań w Szczecinie w okresie od lipca 2005 r. do października 2014 r. Zostały one wyznaczone na podstawie 19730 odnotowanych w tym okresie transakcji, przy czym liczba transakcji w poszczególnych miesiącach kształtowała się od 12 do 273. Zaobserwowane krótkookresowe (z miesiąca na miesiąc) zmiany przeciętnych cen, nawet nieprzypadające na okres hossy (lata 2006-2007), często przekraczały $100 \mathrm{z} / \mathrm{m}^{2}$. Wyznaczone na podstawie tych median indeksy łańcuchowe przedstawiono na rysunku 2 . Widzimy, że przebieg wartości indeksów jest mocno „poszarpany” i że wyznaczone w ten sposób względne wzrosty i spadki przeciętnych cen z miesiąca na miesiąc często wykazują zmiany sięgające kilku procent, a w skrajnych przypadkach przekraczają 10\%. Takie wyniki bez wątpienia należy uznać za niewiarygodne, niereprezentatywne dla rynku.

Wyodrębnianie bardziej jednorodnych grup nieruchomości ze względu na jedną cechę (np. powierzchnię mieszkania) zwykle nie łagodzi efektu poszarpania przebiegu wartości indeksów, gdyż w ten sposób najczęściej znacząco zmniejszamy liczbę transakcji, z których jest obliczana średnie cena, i w konsekwencji mamy do czynienia $\mathrm{z}$ jeszcze mniej reprezentatywną, zróżnicowaną pod względem innych cech grupą nieruchomości. Doskonalenie tych metod powinno więc zmierzać w kierunku wygładzania szeregu czasowego cen jednostkowych i w konsekwencji przebiegu wartości indeksów. Można to czynić na różne sposoby. Pierwszym z nich jest wydłużanie okresów, dla których wyznaczane są średnie ceny transakcyjne (Kokot 2015a). Swego rodzaju ceną, jaką trzeba zapłacić za ten zabieg, jest uzyskanie indeksów dla dłuższych okresów (np. zamiast miesięcznych - kwartalnych), a więc wyników mniej precyzyjnych. Należy się jednak spodziewać, że dla mniej rozwiniętych rynków i taki zabieg okaże się nieskuteczny.

Innymi metodami wygładzania szeregów czasowych są metody mechaniczne, wykorzystujące średnie ruchome, średnie ruchome scentrowane, średnie ruchome ważone itp. lub ich stosowanie sekwencyjne. Ten kierunek działań wydaje się dość obiecujący, zwłaszcza w ujęciu sekwencyjnym. Mankamentem tej metody najczęściej jest „tracenie” obserwacji z początkowych i końcowych okresów (Hozer, Kokot, Kuźmiński 2002). 
Rysunek 1. Miesięczne mediany cen jednostkowych mieszkań w Szczecinie

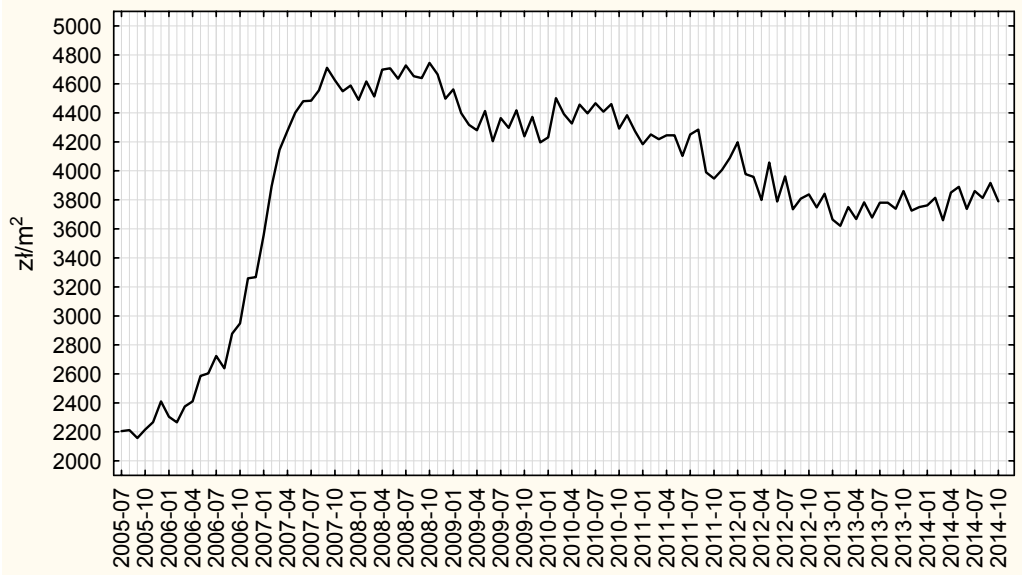

Źródło: opracowanie własne.

Rysunek 2. Indeksy łańcuchowe miesięcznych median cen jednostkowych mieszkań w Szczecinie

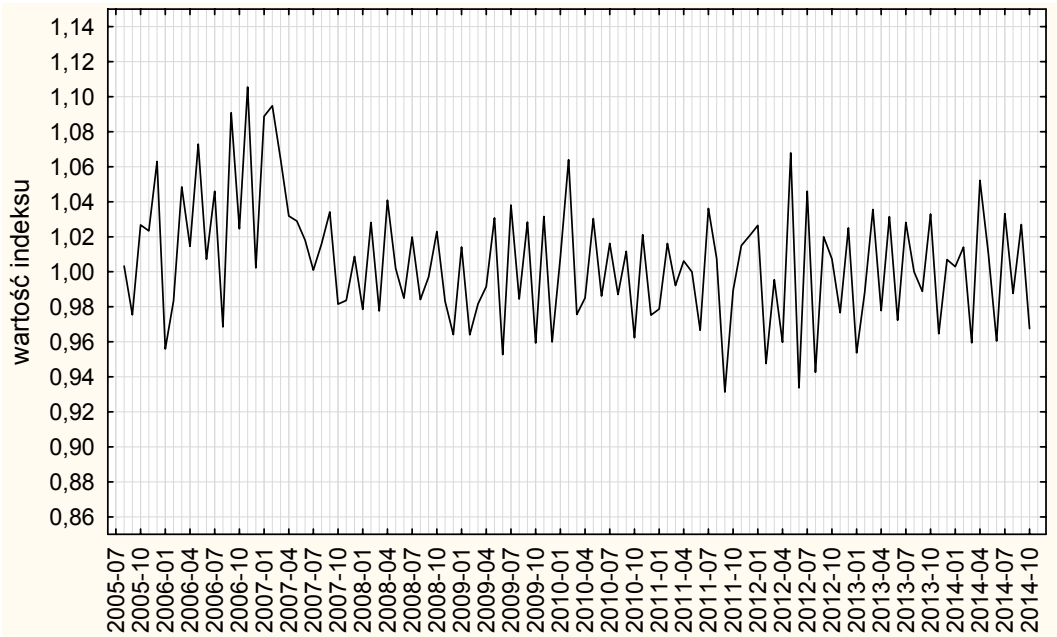

Źródło: opracowanie własne. 
Jeszcze inną metodą wyznaczania indeksów cen nieruchomości na bazie średnich cen jednostkowych jest operowanie cenami ofertowymi zamiast transakcyjnych. Choć średnie ceny ofertowe zazwyczaj cechują inne wartości niż ceny transakcyjne, ich uśrednione ruchy często są podobne. Jest to podejście ciekawe o tyle, o ile wyznaczanie indeksów na podstawie danych ofertowych jest znacznie prostsze niż na podstawie cen transakcyjnych, gdyż ogólnie mówiąc, nie wymaga żmudnego gromadzenia danych o transakcjach na rynku nieruchomości, które często w praktyce i tak okazują się niereprezentatywne dla rynku, gdyż średnie ceny ofertowe dla poszczególnych okresów i rynków lokalnych są często publikowane przez internetowe serwisy ogłoszeniowe. Sporadycznie dotąd publikowane analizy dotyczące problematyki odzwierciedlania ruchów cen na rynku nieruchomości przez ceny ofertowe dają wyniki raczej optymistyczne. Współczynnik korelacji między indeksami przeciętnych kwartalnych cen ofertowych i transakcyjnych w Poznaniu w okresie 1996-2005 uzyskano na poziomie 0,99 (Trojanek 2008), a dla kilkunastu miast w okresie 2006-2012 także uzyskano wartości współczynnika korelacji powyżej 0,9 (dla niektórych miast niższe) (Dittmann 2013). Także wysokie współczynniki skorelowania indeksów jednopodstawowych obliczonych na podstawie cen transakcyjnych i ofertowych odnotowano w latach 2005-2014 dla Szczecina (Kokot, Bas 2015). Podstawowym mankamentem odczytywania średnich jednostkowych cen ofertowych bezpośrednio z publikacji serwisów internetowych jest ulotność tych danych, gdyż serwisy te nie publikują danych archiwalnych, co powoduje konieczność regularnych obserwacji tych publikacji. Do innych mankamentów zaliczyć należy nieznajomość dokładnej metody obliczania średniej ceny przez dany serwis oraz ryzyko zmiany stosowanej metody, a nawet zaprzestania publikacji.

Ad. 2. Metody oparte na analizie powtórnych sprzedaży w najprostszej postaci polegają na obliczeniu indeksów dla poszczególnych nieruchomości, dla których odnotowano transakcję co najmniej dwukrotnie, po czym z takich ,indywidualnych” indeksów wyciąga się średnią dla danego rynku. Ta forma wyznaczania indeksów podlegała licznym modyfikacjom, m.in. przez wprowadzenie wag do budowanych w celu wyznaczenia indeksów modeli czy też stosowanie korekty zmian cech jakościowych nieruchomości. Istotą tych metod jest unikanie problemu niejednorodności grupy nieruchomości stanowiących podstawę wyznaczenia indeksów, gdyż indeksy bazują na zamkniętym zbiorze nieruchomości. Podstawowym problemem występującym przy ich stosowaniu są zmiany dokonywane na nieruchomościach między 
momentami transakcji, które wpływają na uzyskiwane ceny. W polskich warunkach dużo nieruchomości cechuje zły stan techniczny i niski standard. Powszechnie obserwujemy transakcje, w których za „złe” nieruchomości płacone są niskie ceny, po czym ich nabywcy poddają je gruntownym, niekiedy kapitalnym remontom. Zdarza się, że motywacją do zakupu takiej nieruchomości jest zamiar jej odsprzedaży z zyskiem bezpośrednio po remoncie, a na rynku funkcjonują parające się takimi działaniami wyspecjalizowane firmy. Podobna sytuacja ma miejsce na rynku pierwotnym, gdzie transakcje dotyczą nieruchomości w stanie deweloperskim, tzn. bez żadnych elementów wykończenia (podłóg, drzwi wewnętrznych, armatury i urządzeń sanitarnych, oświetlenia itp., a niekiedy nawet ścian działowych). Kiedy po kilku lub kilkunastu latach takie mieszkanie albo dom trafia na rynek, stanowi jakby zupełnie inny „towar”, niż miało to miejsce przy pierwszej transakcji. Indeksy cen wyznaczone na podstawie takich transakcji będą więc zawyżone, choć można spotkać też pogląd, że taki indeks odzwierciedla naturalne zmiany jakości zasobu nieruchomości. Pogląd ten wydaje się jednak fałszywy, gdyż zmiana jakościowa zasobu odnosi się tylko do niewielkiej jego części, a może mocno wpływać na obliczone wartości indeksów. Innym powodem krytyki metod opartych na powtórnej sprzedaży jest to, że powtórna sprzedaż ma miejsce relatywnie rzadko, w szczególności na mało rozwiniętych rynkach, co oznacza, że indeksy są wyznaczane na podstawie tylko niewielkiej części zawartych transakcji. Kolejnym problemem jest standardowe założenie, że w okresie między transakcjami dotyczącymi danej nieruchomości zaobserwowany wzrost (lub spadek) ceny następował jednostajnie. Na podstawie informacji, że po 10 latach nastąpiła odsprzedaż nieruchomości po cenie o 50\% wyższej od ceny jej zakupu, wyciąga się wniosek, że ceny w tym okresie rosły w uproszczeniu o 5\% rocznie, podczas gdy rzeczywiście ten wzrost mógł nastąpić np. w ciągu 3 lat, a przez pozostałe lata ceny były stabilne. Jeszcze innym problemem przy stosowaniu takich indeksów jest sposób gromadzenia danych o transakcjach na rynku nieruchomości, polegający na tym, że poszczególne rekordy bazy transakcji powinny być przypisane poszczególnym nieruchomościom, a nie traktowanym oddzielnie poszczególnym zdarzeniom rynkowym.

Ad. 3. Trzecia grupa metod to te prowadzące do wyznaczenia hedonicznych indeksów cen nieruchomości. Motywacją do ich konstrukcji jest uwzględnienie heterogeniczności nieruchomości, przejawiającej się występowaniem różnych cech u różnych nieruchomości, i założenie, że te cechy mają wpływ na uzyskiwane ceny. 
Najogólniej indeksy hedoniczne powstają na bazie wartości generowanych za pomocą określonego modelu (np. funkcji regresji). Mamy więc do czynienia ze swego rodzaju okresową wyceną reprezentatywnej nieruchomości lub reprezentatywnego koszyka nieruchomości przy użyciu modelu, w którym wartość jest funkcją cech rynkowych nieruchomości. Metody te są realizowane w wielu odmianach wynikających przede wszystkim z rodzaju modeli, na których bazują. Mogą się przy tym posługiwać jednym modelem lub zespołem modeli odrębnie szacowanych dla każdego okresu. Przy metodach bazujących na koszyku nieruchomości powstaje dodatkowo problem modyfikacji tego koszyka tak, aby odzwierciedlał on „typowy” koszyk rynkowy, który zmienia się wraz z rozwojem technologii, zmianą stylu życia społeczeństwa, trendami w zakresie preferencji nabywców itp. Jako podstawową wadę tej metody postrzega się konieczność gromadzenia i stałej aktualizacji wielu informacji i danych niezbędnych do wyceny nieruchomości (Nicholas, Scherbina 2013). Oszacowanie dobrej jakości modelu wymaga bowiem dużych zbiorów obserwacji (Widłak 2010). W szczególności oprócz podstawowych danych o transakcji, jak data jej zawarcia, uzyskana cena, powierzchnia nieruchomości i jej położenie, każda nieruchomość, której transakcja dotyczy, musi być opisana pod względem cech rynkowych, np. stan techniczny budynku, standard lokalu, atrakcyjność lokalizacji, sąsiedztwo, położenie lokalu na piętrze, funkcjonalność lokalu, a pozyskanie takich cech może okazać się bardzo pracochłonne, a nawet niemożliwe. Naturalną konsekwencją istoty tych metod jest to, że uzyskiwane wyniki w dużej mierze zależą od jakości i dokładności odzwierciedlania rzeczywistości przez wykorzystywane modele, na co składają się dwa elementy: jakość danych statystycznych (kompletność, dokładność, jednorodność i ilość) oraz rodzaj i właściwości zastosowanego modelu. Jak nadmieniono we wprowadzeniu, dane o transakcjach na rynku nieruchomości zwykle cechuje słaba jakość statystyczna, a zjawiska zachodzące na rynku nieruchomości trudno się modeluje. Do najczęściej podejmowanych prób modelowania cen na rynku nieruchomości należą modele oparte na funkcjach regresji, zwłaszcza w ujęciu liniowym. Zwykle dają one jednak mało zadowalające wyniki. Przyczyną tego są trudności ze spełnieniem wielu warunków formalnych, jakie są stawiane już na etapie budowy modelu. Należą do nich (Hozer 2001):

a) istnienie dobrej teorii pozwalającej na wyspecyfikowanie zbioru istotnych zmiennych objaśniających;

b) mierzalność istotnych zmiennych; 
c) istnienie i dostępność danych statystycznych o wszystkich zmiennych;

d) silne skorelowanie zmiennych objaśniających ze zmienną objaśnianą i nieskorelowanie ich między sobą;

e) wystarczająco duża zmienność zmiennych objaśniających;

f) uwzględnienie bezpośrednio w modelu wszystkich najważniejszych zmiennych objaśniających;

g) trafne dobranie postaci analitycznej modelu;

h) stabilność oszacowanych relacji;

i) nielosowość zmiennych objaśniających.

Ponadto uzyskanie modelu względnie dobrej jakości wymaga praktycznie zawsze „ręcznej” ingerencji w bazę transakcji, polegającej na eliminacji obserwacji ewidentnie destrukcyjnie wpływających na właściwości modelu. Zwykle są to obserwacje dotyczące transakcji o najniższych i najwyższych cenach. Zabiegi takie jednak nie eliminują transakcji, w których, co prawda, uzyskano typowe ceny, ale cechy nieruchomości nie konweniują z tymi cenami (np. za nieruchomość bardzo dobrze skalsyfikowaną pod względem wszystkich cech rynkowych odnotowano cenę na średnim poziomie).

Dotychczasowe publikowane próby wyznaczania indeksów hedonicznych w Polsce nie napawają pesymistycznie. Zwraca jednak uwagę fakt znaczącego zróżnicowania wyników w zależności od zastosowanej metody szczegółowej (patrz m.in. Tomczyk, Widłak 2010). Indeksy hedoniczne są w praktyce liczone w ramach analiz prowadzonych przez Narodowy Bank Polski, który publikuje kwartalnie „Informacje o cenach mieszkań i sytuacji na rynku nieruchomości mieszkaniowych i komercyjnych w Polsce" (dostępne na stronach internetowych NBP), wyznaczając ceny mieszkań, korygowane indeksami hedonicznymi, dla Warszawy, łącznie dla 6 największych miast (Gdańsk, Gdynia, Kraków, Łódź, Poznań, Wrocław) i łącznie dla kolejnych 10 miast (Białystok, Bydgoszcz, Katowice, Kielce, Lublin, Olsztyn, Opole, Rzeszów, Szczecin, Zielona Góra).

\section{Podsumowanie}

Należy stwierdzić, że każda metoda wyznaczania indeksów cen nieruchomości ma swoje wady i zalety oraz inny poziom podatności aplikacyjnej. Podstawową zaletą metod polegających na obserwacji zmian średnich cen jest prostota obliczeń, 
natomiast wadą to, że w różnych okresach średnie mogą być obliczane w próbach zróżnicowanych pod względem struktury jakościowej. Indeksy wyznaczane z odpowiednio wygładzonych szeregów czasowych średnich cen mogą jednak całkiem dobrze odzwierciedlać rzeczywiste ruchy cenowe na rynku. Głównym mankamentem metod wyznaczania indeksów na podstawie powtórnej sprzedaży tej samej nieruchomości są zmiany, jakie bywają dokonywane na nieruchomości w okresie między poszczególnymi transakcjami, które wpływają na uzyskiwane ceny. Natomiast metody wykorzystujące modele hedoniczne wymagają gromadzenia i stałej aktualizacji wielu informacji i danych niezbędnych do wyceny nieruchomości, a wyniki są skażone wadami danych oraz niedoskonałością zastosowanych modeli. Warto też wskazać, że przedstawione metody bywają stosowane nie tylko w różnych odmianach, ale też w sposób hybrydowy (Trojanek 2008).

\section{Literatura}

Bokhari S., Geltner D. (2010), Estimating Real Estate Price Movements for High Frequency Tradable Indexes in a Scarce Data Environment, „The Journal of Real Estate Finance and Economics", vol. 45, $\mathrm{nr} 2$.

Clapp J.M., Giacotto C. (1992), Estimating Price Indices for Residential Property: A Comparison of Repeat Sales and Assessed Value Methods, ,Journal of the American Statistical Association", vol. 87.

Dittmann I. (2013), Primary and secondary residential real estate markets in Poland - analogies in offer and transaction price development, „Real Estate Management and Valuation", vol. 21, $\mathrm{nr} 1$.

Francke M.K. (2010), Repeat Sales Index for Thin Markets, „The Journal of Real Estate Finance and Economics", vol. 41, nr 1.

Guo X., Zheng S., Geltner D., Liu H. (2014), A new approach for constructing home price indices: The pseudo repeat sales model and its application in China, „Journal of Housing Economics", vol. 25.

Hozer J. (2001), Regresja wieloraka a wycena nieruchomości, „Rzeczoznawca Majątkowy”, nr 2.

Hozer J., Kokot S., Kuźmiński W. (2002), Metody analizy statystycznej rynku w wycenie nieruchomości, Polska Federacja Stowarzyszeń Rzeczoznawców Majątkowych, Warszawa. 
KokotS.(2014), Teoretyczne i praktyczne problemy wyznaczania indeksów cen nieruchomości, Zeszyty Naukowe Uniwersytetu Szczecińskiego, nr 811, „Studia i Prace Wydziału Nauk Ekonomicznych i Zarządzania”, nr 36: Metody ilościowe w ekonomii, t. 2.

Kokot S. (2015a), Przyczynek do badań nad indeksami cen nieruchomości, „Wiadomości Statystyczne", $\mathrm{nr} 4$.

Kokot S. (2015b), Parę krytycznych uwag na temat jakości danych o transakcjach nieruchomościami, „Biuletyn Polskiego Stowarzyszenia Rzeczoznawców Wyceny Nieruchomości”, nr 102.

Kokot S., Bas M. (2013), Evaluation of the applicability of statistical methods in studies on price dynamics on the real estate market, „Real Estate Management and Valuation”, vol. 21, nr 1.

Kokot S., Bas M. (2015), The comparative analysis of asking and traded price indices in different floor area subsegments of the residential property market, „Real Estate Management and Valuation", vol. 23, nr 3.

Nicholas T., Scherbina A. (2013), Real Estate Prices During the Roaring Twenties and the Great Depression, „Real Estate Economics”, vol. 41, nr 2.

Tomczyk E., Widłak M. (2010), Konstrukcja i własności hedonicznego indeksu cen mieszkań dla Warszawy, „Bank i Kredyt”, vol. 41, nr 1.

Trojanek R. (2008), Wahania cen na rynku mieszkaniowym, Wydawnictwo Akademii Ekonomicznej w Poznaniu, Poznań.

Ustawa o gospodarce nieruchomościami z 21 sierpnia 1997 r., t.j. DzU z 2015 r., poz. 782.

Widłak M. (2010), Metody wyznaczania hedonicznych indeksów cen jako sposób kontroli zmian jakości dóbr, „Wiadomości Statystyczne”, nr 9.

Wood R. (2005), A Comparison of UK Residential House Price Indices, „Bank of International Settlements Papers", nr 21.

\title{
A FEW COMMENTS ABOUT THE METHODS OF DETERMINING PROPERTY PRICES INDICES
}

\begin{abstract}
Real estate price indices are valuable information for analysts, investors and representatives of other professions operating on the real estate market. Furthermore, in accordance with the applicable regulations, they should be applied in specific legal purposes. In practice, there are several methods of determining the real estate price indices. All of them have their
\end{abstract}


advantages and disadvantages and reflect actual price movements on the market with different accuracy. This article is an attempt to characterize each group of methods, in particular from the point of view of potential risks of the results credibility.

Translated by Sebastian Kokot

Keywords: real estate market, property prices indices

JEL Codes: C43, R20, R32 
